ISSN 2078-6441. Вісник Львівського університету. Серія географічна. 2014. Випуск 47. С. 30-41. Visnyk of the Lviv University. Series Geography. 2014. Issue 47. P. 30-41.

911.3:502.4

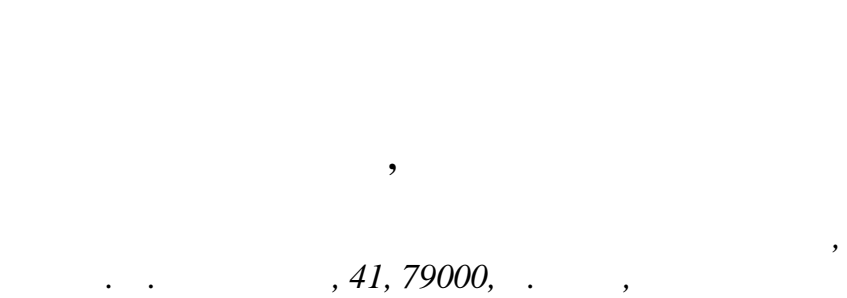

ведено перелік і сх р ктеризов но суч сний ст н охорони п м'яток неживої природи (геологічні, геоморфологічні, гідрологічні) лицького ридністер'я в р йоні розт шув ння лицького н ціон льного природного п рку. ро н лізов но можливості використ ння п м'яток неживої природи в рекре ційно-туристичній діяльності лицького, , розроблено мережу одно- і б г тоденних геотуристичних м ршрутів. озглянуто перспективи створення н ціон льного геоп рку “ лицьке ридністер'я”.

лючові слов : п м'ятки неживої природи, геологічні, геоморфологічні й гідрологічні п м'ятки природи, геотуристичні м ршрути, н ціон льний геоп рк, лицьке ридністер'я, лицький н ціон льний природний п рк.

лицьке ридністер'я окреслюють як регіон, розт шов ний уздовж ністр від ур вненської долини прориву до поч тку ністерського к ньйону в місці конт кту південно-з хідної окр їни хідноєвропейської пл тформи і овнішньої зони ередк рп тського прогину т, відповідно, двох геоморфологічних кр їн - уської рівнини й кр їнських рп т [32, 33]. гідно зі схем ми геоморфологічного р йонув ння . ися [29] i . p вчук [20], у лицьке ридністер'я треб включити т кі р йони одільської т ередк рп тської височин: івденноопільську височину і истрицьколум цьке ( ридністерське) пілля т ойнилівську, ліську й рилуквинську височини, лицько- ук чівську, истрицьку ( т нісл вську) і луську улоговини.

оз їчн сільськогоспод рсько-лучно-лісов територія лицького ридністер'я поєднує височинні й річково-долинні передгірні т височинні опільські л ндш фти.

цьому м льовничому куточку кр їни 2004 р. створено лицький н ціон льний природний п рк ( ) площею 14684,8 г н землях лісового фонду лицького держлісгоспу. н ціон льний п рк увійшли комплексн п м'ятк природи “ сов гор ” (65 г), урштинське водосховище (1 260 г), окремі рибогоспод рські ст ви у долин х р ївки і ебелки, ст ричні озер в долині ністр . тже, лицький м $е$ кл стерну територі льну структуру, як визн ч є особливості його функціон льного зонув ння, можливості з безпечення диференційов ного з повідного режиму т умови розвитку рекре ції і туризму. жливим елементом розвитку туризму й рекре ції поряд з історико-культурними об'єкт ми ціон льного з повідник ( ) “ вній лич” є п м'ятки неживої природи, як елементи експонув ння н екотуристичних м ршрут х і еколого-пізн в льних стежк х [6, 17]. одноч с бг тство геотуристичних тр кцій досліджув ної території д $є$ змогу в н йближчому м йбутньому створити головно н б зі лицького і “ вній лич” н ціон льний геоп $р \kappa$, який може ст ти одним із перших в кр їні $[12,21,30]$.

(C) рус к ., ляниця ., 2014 
ш мет - уз г льнити д ні про п м’ятки неживої природи ( ) лицького ридністер'я для їхньої оцінки т розробки перспективних геотуристичних м ршрутів, які можн використовув ти в лицькому , т кож розглянути перспективи створення н ціон льного геоп рку “ лицьке ридністер'я”. ля ре ліз ції з зн ченого розпоч то інвент риз цію і к ртогр фув ння лицького ридністер'я 3 ст нд ртизов ними бл нк ми опису “ ідслонення гірських порід”, “ келі (горбиост нці, визн чні вершини)”, “ зеро”, “ жерело”, “ рстові утворення”, зі змістом яких можн озн йомитись в окремих публік ціях [5, 11]. икорист но д ні про п м'ятки природи регіону, н ведені в довідник х “ еологические п мятники кр ины” [19], “ риродно-з повідні території т об’єкти в но- р нківщини” [23], “ еологічний путівник в но- р нківської обл сті” [22], вивчено пр ці . удницького [26], групи дослідників, очолюв них професор ми огуцьким і итником [1-4, 27, 28, 32, 33], . ов льської [16-18], т кож результ ти вл сних польових досліджень, отрим ні під ч с розробки “ роекту орг ніз ції території лицького , охорони, відтворення i рекре ційного використ ння його природних комплексів і об'єктів”, у 2006-2010 pp. [24, 25].

н уковій літер турі тр диційно сформув лось розуміння тільки як геологічних, що охоплюють як суто геологічні, т к і геоморфологічні й гідрологічні об'єкти. окрем , у путівнику-довіднику “ еологические п мятники кр ины” [19] геологічні $n$ м'ятки розділено 3 предметним принцииом н т кі типи: 1) стр тигр фічні т геохронологічні; 2) мінер лого-петрогр фічні; 3) п леонтологічні; 4) тектонічні; 5) геоморфологічні; 6) м льовничі. ьогодні геологічні п м’ятки кр їни поділяють н 15 типологічних груп з змістовним принципом [9].

ід $\boldsymbol{n}$ м'ятк ми неживӧ̈ природи розуміємо дет льно вивчені ет лони природних феноменів чи типові природні утворення 3 доброю морфологічною вир женістю (відслоненістю). в ж ємо, що всі п м'ятки неживої природи можн розділити н три кл си відповідно до головного об'єкт їхньої цінності для охорони [5]. еологічні $n$ м'ятки природи - це цінні геологічні відслонення, п леонтологічні й тектонічні об'єКти тощо, геоморфологічні - форми рельєфу різного генезису, гідрологічні - водні об'єкти. кремі п м'ятки м ють комплексну цінність, можуть т кож виділяти підкл си п м’яток - геолого-геоморфологічні, гідролого-геоморфологічні тощо. проби упорядкув ння принципів кл сифік ції геологічних і геоморфологічних п м'яток природи зроблено в окремих пр цях $[5,10,11]$.

йвизн чніш природн тр кція лицького ридністер'я - долин ністр , популярний серед туристів водний шлях. йцік вішим $є$ фр гмент м льовничої ділянки коритоподібної долини ністр між м. лич т сел ми ріямпіль і овге з плоскорівнинним днищем, яке ускл днене ст ричними озер ми і ст рицями н різній ст дії їхнього з рост ння. орти долини ністр предст влені крутими, місцями урвистими схил ми-стінк ми з численними виход ми порід різного геологічного віку (верхньої крейди, міоцену, пліоцену, плейстоцен-голоцену). одекуди тр пляються виходи підземних вод, н йвідомішим 3 яких є джерело біля с. ріямпіль, яке 3 поширеними у кр ю легенд ми м є лікув льні вл стивості. трімкі схили ністр вкриті перев жно гр бово-дубовими ліс ми. змістом і цінністю долину ністр можн 3 числити до комплексних п м'яток. ьогодні русл річки ністер (820г) i урштинське водосховище (1 260г) м ють ст тус -територій, які в жливі для існув ння водопл вних пт хів. 2012 р. под но з явку про н д ння з зн ченим 
територіям ст тусу мс рських угідь - територій, що м ють міжн родне зн чення як середовищ існув ння водопл вних пт хів [24].

особливу природоохоронну і водноч с природно-пізн в льну ув гу у меж х

лицького ридністер'я з слуговують: термофільн лучно-степов і $н$ скельностепов рослинність, що сформув л сь н виход х гіпсів і гіпсо нгідритів, рідше в пняків (урочищ сов ор біля с. овшів, мінь біля с. ежигірці, к л біля с. оділля, ручев біля с. итятин тощо) і водно-болотн рослинність (урочищ оролівк i лісця біля лич, ст ричні озер біля сіл одники, ріямпіль) т х р ктерні для межиріч численні $\kappa$ рстові явищ, в урочищ х ом'ярки і ербівці біля c. имерівці т в околицях сіл едині, окіл, умир, зерни, нусівк (зокрем , лійки і колодязі (глибиною до 20-30 м), печери і гроти, рки, “сліпі долини”, к рстові озер й озер -вікнини, високодебітні джерел), т кож скельні утворення (г. орсуч і ост нець “динокий” в ур. ом'ярки, “ ожий видок” в ур. мінь, “товпи” в ур. к л , “ олов ” біля с. зеряни, “ ор івоч ” біля с. ремидів, скелі біля с. окіл і г. исої біля с. нусівк т в ур. линовище вздовж пр вого борту р. истриця тощо). перелічених об'єктів більшість розт шов н н території лицького

нік льними об'єкт ми неживої природи регіону є мезозой-к йнозойські природні т штучні відслонення, предст влені відкл д мИ верхньої крейди - мергелі і в пняки (потужністю до 15-20 м), т середнього і верхнього б дену - гіпси, р тинські в пняки (потужністю, відповідно, до 30 і 10 м), грунтово-лесові й люві льні покриви плейстоцену, т кож поверхневі і підземні к рстові форми, що утворились у відкл д х гіпсо нгідритової товщі середнього б дену (неоген). еред цих цік вих утворень печери, гроти, колодязі, озер , понори, к рри, гіпсові ост нці т рки. б'єкти неживої природи м ють високий рекре ційний потенці л, про що, зокрем , йшлося у публік ціях окремих дослідників [6-8, 16, 17, 22].

ерелічимо н йцік віші п м'ятки неживої природи території досліджень, які віднесені до різних кл сів (рис. 1). еред геологічних $\boldsymbol{n}$ м'яток н звемо т кі:

1.1) убівецький $\kappa p^{\prime} \epsilon p$, н стінк х якого відслонені мергелі, пис льн крейд i в пняки туронського й коньяцького ярусів верхньої крейди; гіпсо нгідритовий горизонт (тир ськ світ неогену); товщ четвертинних лесових суглинків з п леонтологічними рештк ми і п леолітичним м тері лом [22];

1.2) $к p^{\prime} \epsilon p$ біля г. івоч (1 г ) з ет лонним розрізом світло-сірих і білих в пняків туронського ярусу верхньої крейди зі стяжіннями чорного кремнію [6, 7];

1.3) відслонення мергелів верхньої крейди у підніжжі сової гори $(0,1$ г , кв. 36 урштинського лісництв лицького ), у якому добре простежується три ш ри кори звітрюв ння мергелів, їхня вертик льн і горизонт льн тріщинув тість [6, 7];

1.4) стрімкий $n p$ вий берег укви біля сіл рилос $i$ ікторів з ввишки до $30 \mathrm{M}, \mathrm{H}$ якому відслонені сірув то-жовті й голубув то-сірі мергелі коньяцького ярусу верхньої крейди [22], що перекриті потужною товщею (до 3-5 м) руслового і 3 пл вного лювію, імовірно, четвертої тер си ністр ;

1.5) стр тифіков ні розрізи четвертинних відкл дів олодіїв, лич $i$ лич, груп розрізів біля смт зупіль з п леолітичним м тері лом, дет льно досліджені н уковою групою, яку очолюють професори огуцький і итник [1-4, 27, 28, 32, 33].

еред інших об'єктів т кого типу з зн чимо: 1.6) розрізи четвертинних відкл дів ежигіриі [11, 13-15] і ріямпіль; 1.7) руслову ф цію пліоценового лювію н 2. $\quad$ р сн (352 м); 1.8) д вні річкові відкл ди біля c. итятин, які описув в ще . удницький [26]; 


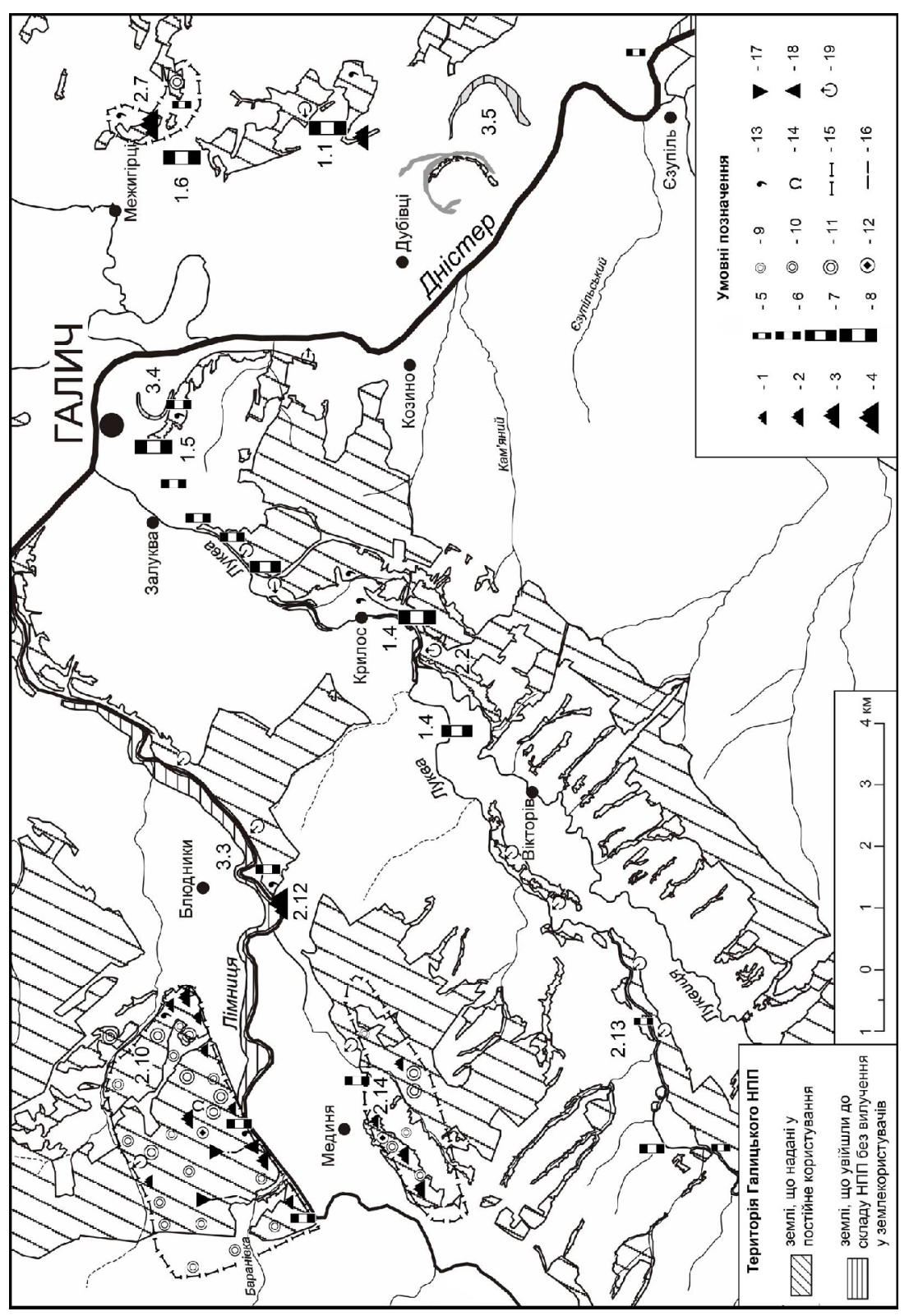

菊

$\sum \sum_{i} \tilde{\otimes}$

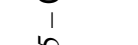

원

¿

$\because \stackrel{0}{0} \ddot{\Sigma}$

릴 똥요

월

-

응

至 1

変茫

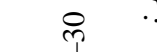

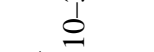

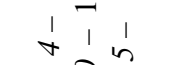

봅의

光茫芒

느응

궁

$\gtreqless n 1$ क्ष

范方光

:- 元

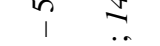

产

向 0

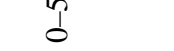

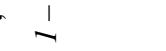

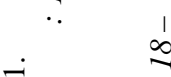

过苛 
1.9) урочище нийон біля с. нусівк - яр глибиною до 15-17 м у мергелях коньяцького ярусу з добре вир женою системою тектонічних і седимент ційних тріщин;

1.10) к р’ер біля с. обережжя, у якому відслонен товщ (до 12-15 м) лесових суглинків середнього і верхнього плейстоцену;

1.11) стр тифіков ні розрізи четвертинних відкл дів біля с. овге, які ідентифікують як розрізи четвертої, п’ятої і шостої н дз пл вних тер с ністр [3].

кремі з перелічених геоморфологічних об’єктів м ють т кож геологічну цінність, оскільки у їхніх меж х можн спостеріг ти різні зр зки гіпсів і гіпсо нгідритів, зокрем , урочищ келя біля с. оділля, уроп тницький к мінь, ежигірський к мінь тощо. роте більшу цінність ці об'єкти м ють як геоморфологічні п м'ятки.

еред геоморфологічних $\boldsymbol{n}$ м'яток виділяють:

2.1) урочище еліїв (129 г , кв. 24 лицького лісництв лицького ) $з$ горбистим ерозійним рельєфом, який х р ктерний для скульптурної івденноопільської височини. ут тр пляються виходи гіпсо нгідритів н невисоких скелястих схил х 6 лок т у неглибоких к рстових лійк х;

2.2) урочище рилос (389 г ) н пр вобережжі укви (кв. 13-16 рилоського лісництв лицького ), де н стрімких схил х рилуквинської височини простежуються у вигляді м льовничих скель виходи гіпсів і гіпсо нгідридів міоцену т мергелів верхньої крейди;

2.3) ст ричне зниження урочищ, лісия $(5,0$ г ) н північній околиці м. лич, у меж х якого зрост є популяція рідкісного виду - рябчик ш хового [23];

2.4) урочище орчев (88 г, кв. 6 урштинського лісництв лицького ) фр гмент високої з пл ви ністр, вкритої сирими дібров ми і вільшняк ми з вільхи чорної;

2.5) м льовниче ост нцеве п смо сов гор (65 г ) 3 х р ктерним поєдн нням хвилястих п горбів т гіпсових скель, що простяг ються вздовж лівого берег урштинського водосховищ . рочище є однією 3 н йліпше вивчених лучно-степових ділянок пілля [23, 24]. схил $\mathrm{x}$ сової гори у шурфі н висоті близько $310 \mathrm{м}$ виявлено дрібну г льку і гр вій з мергелів, в пняків і к рп тських роговиків;

2.6) урочище $к л$ (скельно-флористичний резерв т “ мінь”, 5 г ) біля с. оділля - н йм сшт бніше у лицькому р йоні скельне утворення у вигляді веж і скельної стіни висотою до 28-30 м (див. рис. 2), які є типовими для ог тинського пілля. ут н явні невеликі гроти (печер “ ліпої вчительки”), прохідні коридори, ркоподібні утворення тощо [16];

2.7) урочище ежсигірський мінь (кв. 8 лицького лісництв лицького , 10,5 г ) - унік льн скельн стін, скл ден гіпс ми й гіпсо нгідрит ми різної текстури 6 денського ч су. рочище відоме оригін льними м льовничими скелями (“ ожий видок"), грот ми і н скельно-степовою рослинністю;

2.8) урочище уроп тницький мінь (кв. 6 урштинського лісництв лицького , 10 г ) - ост нцевий п горб з ввишки 50 м зі скельними виход ми крист лів ш блеподібних гіпсів у вигляді зірок (див. рис. 3);

2.9-2.10) к рстові утворення в урочищ х ом'ярки (кв. 23-25 людниківського лісництв лицького , 85 г ) і ербівці (кв. 21 людниківського лісництв

лицького , 45 г ) н лівобережжі імниці - комплекс лійок, колодязів, гротів і печер, виходів підземних потоків т м льовничих скель у меж х ярково-б лкових форм, які м ють н укове, природно-пізн в льне і рекре ційне (спелеологічне) зн чення [7, 17]; 


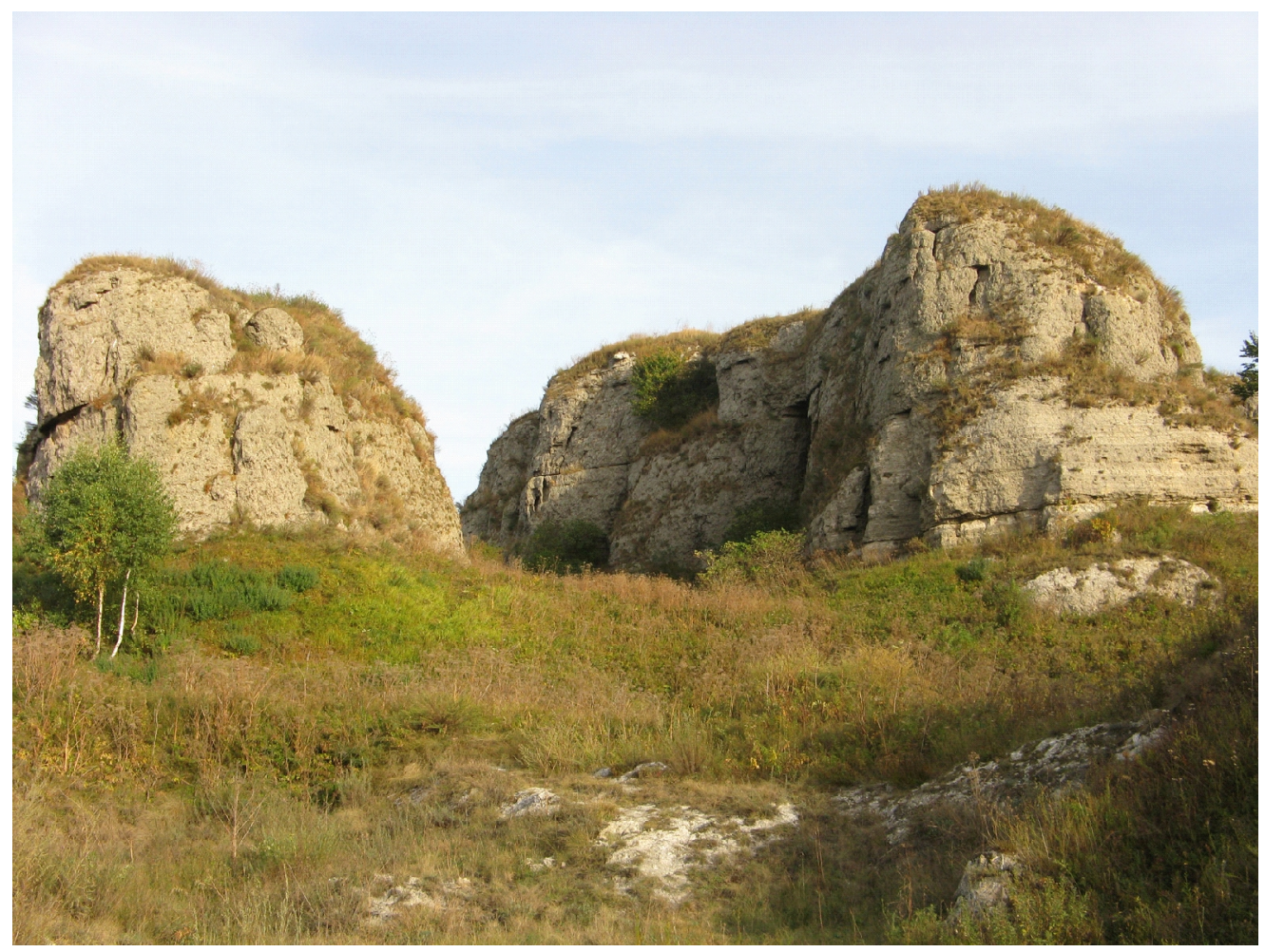

ис. 2. келі в урочищі к л біля с. оділля

2.11) урочище зерянський мінь (кв. 8-10 урштинського лісництв лицького , 100 г ) - ост нцеві п горби з ввишки 50-70 м, відокремлені “сліпою долиною" з лійк ми і понор ми, скельними виход ми сульф тних порід;

2.12) окільські скелі (кв. 3 рилоського лісництв лицького , 3 г ) з ввишки 30 м з грот ми і печер ми, скл дені гіпсо нгідрит ми і гіпсом- леб стром;

2.13) зсувні схили з ктивними зсув ми вздовж лівих берегів річок укви (кв. 16-18 рилоського лісництв лицького ) i уквиці (кв. 20, 21, 23 рилоського лісництв ) і $\mathrm{cm}$ білізов ними зсув ми (кв. 29-30 рилоського лісництв ) т вклинюв нням підземних вод у вигляді джерел;

2.14) урочище единя (кв. 6, 8, 9 рилоського лісництв лицького , 70 г ) фр гмент середніх тер с імниці, ускл днений к рстовими утвореннями.

гідрологічних п м'яток природи виділяють: 3.1,3.2) к рстові озер

лицького лісництв лицького , 1 г (див. рис. 4)) і орониця (кв. 5 лицького лісництв , 0,5 г ) - н йбільші озер к рстового походження в лицькому р-ні; 3.3) рік імниц з водоохоронною смугою шириною 100 м вздовж берегів (376 г ) - типов для ередк рп ття ділянк ме ндрової долини з численними рук в ми, перек т ми і плес ми; 3.4, 3.5) ст ричні озер оролівк (2 г ) і одники (62,3 г ) - ш блеподібн ст риця 3 вдовжки до $2 \mathrm{KM}$, як є однією з н йбільших у долині ерхнього ністр 3 популяцією водяного горіх пл в ючого [29]; 3.6) з болочен ст риця ністр урочище іля ринополя $(33,1$ г $) ; 3.7,3.8)$ озер -вікнини у с. зерце $(0,2$ г $)$ і с. гір'я 
укольницьке $(0,1$ г ) з потужними виход ми підземних вод; 3.9, 3.10) високодебітні джерел підземних вод ибло біля с. бережн і лючемиї біля с. итятин.

зн чимо, що н ведений перелік п м'яток неживої природи в ході польових досліджень доповнюв тимемо новими об'єкт ми.

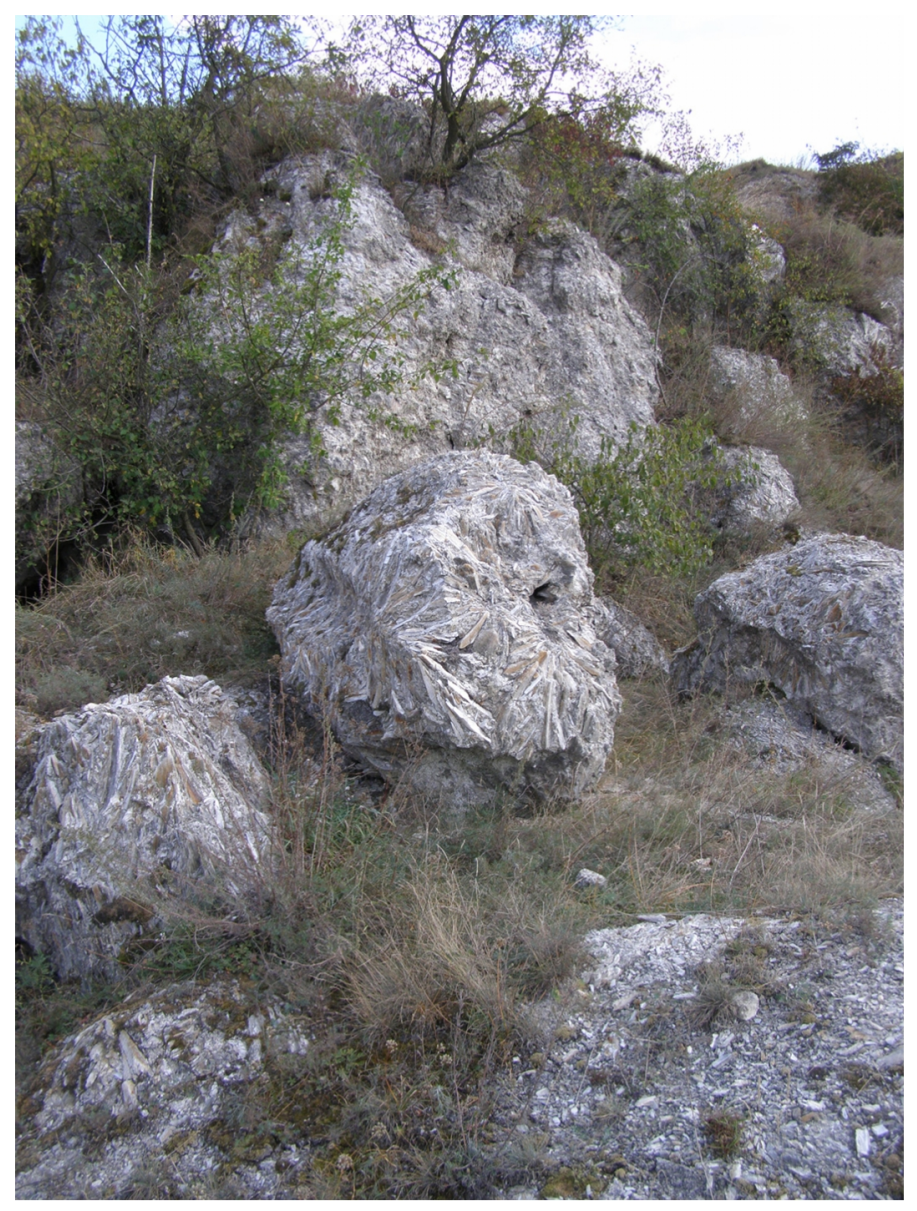

ис. 3. кельні виходи крист лів ш блеподібних гіпсів в урочищі уроп тницький мінь біля с. уроп тники

ерспективи екотуристичного використ ння п м'яток неживої природи т створення геоп рку “ лицьке ридністер'я".

метою популяриз ції п м'яток неживої природи лицького р-ну різні втори розробили низку туристичних м ршрутів, які охоплюють н йцік віші природні об'єкти регіону т $є$ основою розвитку геотуризму. еотуризм - це розділ пізн в льного туризму, що грунтується н вивченні геологічних і геоморфологічних об'єктів і процесів, т кож отрим нні від конт кту з ними естетичних вр жень [12]. оряд з орнітологічним туризмом геотуризм повинен ст ти м рковим турпродуктом лицького 
[25]. ля його розвитку . учко розробив еколого-пізн в льні стежки “ здовж урштинського водосховищ ” і “ риборозплідні ст ви”, які ктивно використовують у рекре ційній діяльності

р цівники розробили і використовують одноденні туристичні м ршрути “ орониця- імлин”, “няж криниця- мков гор ” “ “о личинських печер” т екопізн в льні стежки “ о іброві” і “ сову ору”, тр кційними елемент ми яких ч стково є об'єкти неживої природи. л сне геотуристичною спеці ліз цією вирізняються м ршрут “ о личинських печер” т проектов ні м ршрути “ міньімлин” і “ о одільських печер”.

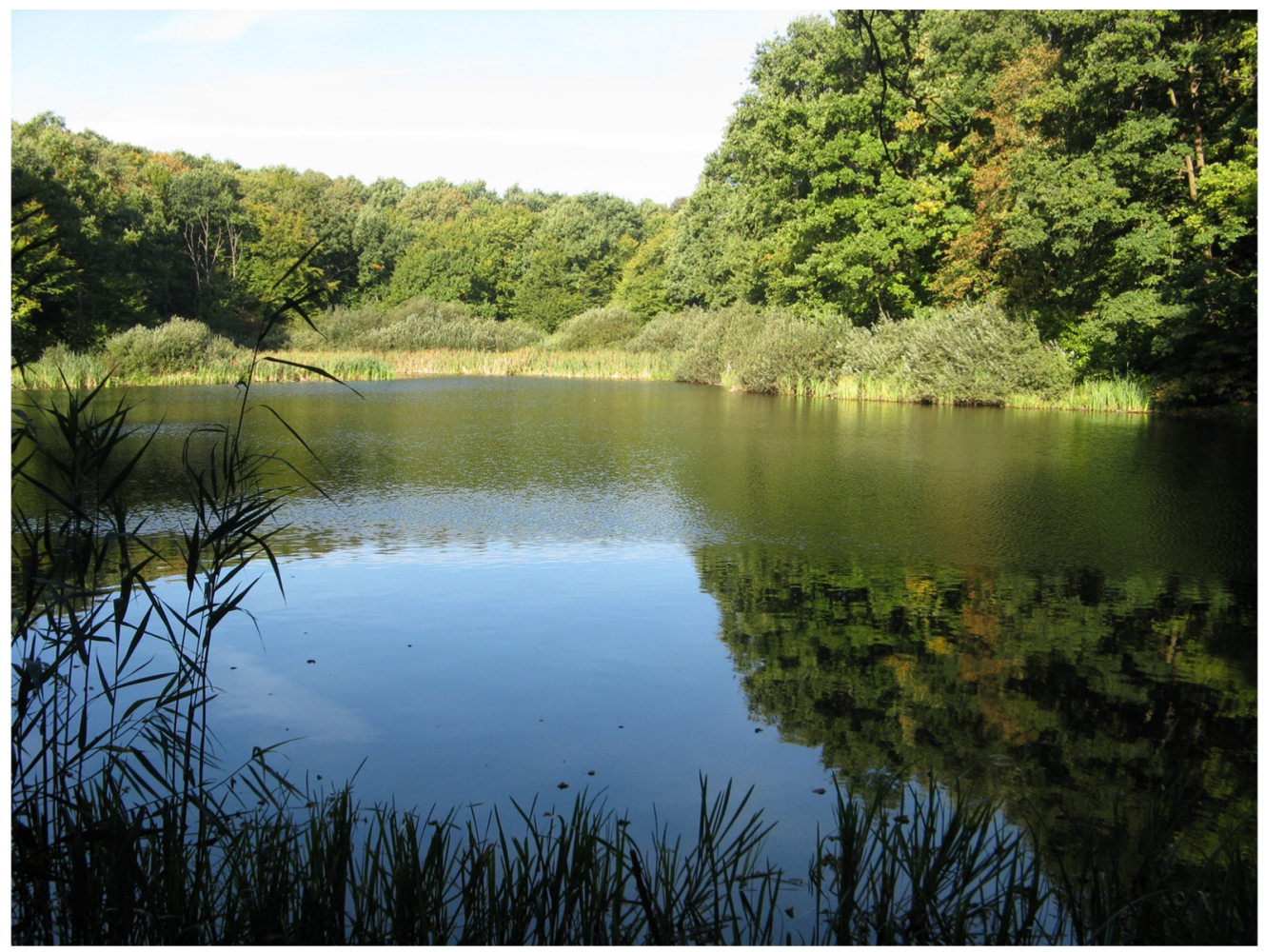

ис. 4. рстове озеро імлин біля с. едух

дноденні геотуристичні м ршрути розроблені геолог ми 3 в но- $\mathrm{p}$ нківськ : 1) до убівецького к р’єру, 2) до с. рилос н пр вий берег річки укви, 3) н лівий берег річки імниці [22]. ст нній ч стково збіг ється з м ршрутом “ о личинських печер".

“ роекті орг ніз ції території лицького " "25] розроблено кільк денні піші геотуристичні м ршрути: № 1 (лінійний) оділля- зеряни- уроп тники- оростовичі- овшів- ільшівці- уст нь- лич; № 2 (кільцевий) едух - ишів- інч кизерце- ремидів- умир- ріямпіль- одники- ежсигірці- едух ; № 3 (лінійний) 
рилос- ікторів- ом рів- окіл- людники- единя, які дет льно опис ні в окремій публік ції [6].

зн чені м ршрути можуть бути використ ні лицьким для рекре ційної й еколого-освітньої діяльності т поєднув ти в собі як скл дові елементи екологопізн в льні стежки, розроблені пр цівник ми лицького . окрем, під ч с проходження м ршруту № 1 можн відвід ти екопізн в льні стежки “ сову ору” т “ здовж урштинського водосховищ ”, у м ршрут № 2 включити екопізн в льну стежку “ риборозплідні ст ви”, у м ршрут № 3 - екопізн в льну стежку “ о іброві”.

риродні т штучні (к р’єри) відслонення в лицькому ридністер’ї д ють змогу простежув ти історію розвитку окр їни хідноєвропейської пл тформи і овнішньої зони ередк рп тського прогину протягом крейдового-четвертинного періодів. окрем , тут фіксують опорні розрізи стр тигр фічних горизонтів крейди (дубовецьк світ $\left(\mathrm{K}_{2} d b\right)$ туронського і коньяцького ярусів, луквинськ світ $\left(\mathrm{K}_{2} l k\right)$ с нтонського ярусу) [22]. е репрезент тивний регіон з розвитком потужної товщі гіпсо нгідритових порід тир ської серії верхнього б денію т грунтово-лесових і люві льних покривів плейстоценового ч су, т кож модельний $\mathrm{p}$ йон для вивчення розвитку долини p. н ністер у пліоцен-плейстоценовий ч с [2, 3, 8, 22, 31].

ротягом ост ннього десятиліття н підст ві комплексного дослідження покривних лесових товщ н тер сових розріз х у личі, зуполі, олодієві, овгому, ріямполі,

гвізді т інших опр цьов но регіон льну стр тигр фічну схему лесів і викопних грунтів плейстоцену $[2,3,27,32]$. егіон є унік льним щодо вивчення історії з селення людиною цієї місцевості $[13,14,32,33]$. ет льно вивчені п леолітичні стоянки в ежигірцях, личі т зуполі $[1,4,8,15,27,28]$. ропонов н територія прив блив для геон укових т геоосвітніх 3 нять 3 вдяки широкому спектру геоморфологічної проблем тики: річкові тер сові комплекси ністр т його приток, різном нітні к рстові форми (лійки, печери, к рстові долини), структурно-денуд ційний рельєф, гр віт ційні форми (зсуви, осипищ ), суч сні ерозійно- кумулятивні процеси у днищі долини ністр і його приток.

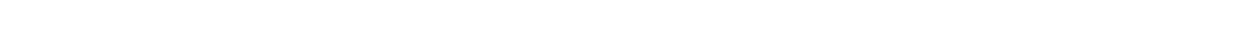
zеоп рку “ лицьке ридністер'я”, який в орг ніз ційному пл ні пропонуємо створити н б зі лицького , де взято під охорону н йцік віші геологогеоморфологічні утворення. геоп рк треб включити ціон льний 3 повідник “ вній лич” з цік вими нтропогенними (фортифік ційні споруди середньовіччя рови, в ли) і природними форм ми рельєфу. крім того, до скл ду геоп рку може ввійти низк комплексних з повідних об'єктів, н прикл д, л ндш фтний з к зник з г льнодерж вного зн чення “ оз ков долин ” н лівобережжі истриці ( истрицько- лум цьк височин ). о інформ ційно-інфр структурних об'єктів, що з безпечув тимуть викон ння н уково-освітніх функцій проектов ного геоп рку, м ють н леж ти: 1) музей лицького “рирод емлі лицької” н лич- орі, у якому треб зб г тити геолого-геоморфологічну експозицію; 2) музей історії д внього лич у c. рилос (з посиленням елементів рхеології кр ю-експон т ми п леоліту і неоліту); 3) ністерський геогр фічний ст ціон р ьвівського н ціон льного університету імені в н р нк у смт зупіль з відповідною н уково-освітньою 6 зою $[12,21,30]$. 
1. огуцький . леолітичн стоянк лич : проблеми стр тигр фії т хронології / . огуцький, . нчонт, . итник [т ін.] // тері ли і дослідження з рхеології рик рп ття і олині. - 2010. - ип. 13. - . 17-46.

2. огуцький . . ро покривні лесово-грунтові товщі н тер с $\mathrm{x}$ ередк рп ття i ридністерського оділля т люві льне походження лесів / . огуцький, . цишин, . митрук [т ін.] // ізичн геогр фія і геоморфологія. - 2011. ип. 3 (64). - . 144-153.

3. огуцький . . исокі тер си ністр в околицях с. овге н в но- $\mathrm{p}$ нківщині / . огуцький, . цишин, . митрук [т ін.] // існик ьвів. ун-ту. ер. геогр. 2012. - иП. 40, ч. 1. - . .123-131.

4. огуцький . . зупіль VII-IX - нові розрізи плейстоценових відкл дів лицького ридністер'я / . огуцький, . нчонт, . итник [т ін.] // роблеми геоморфології і п леогеогр фії кр їнських рп т і прилеглих територій : б. н ук. пр ць. - ьвів : $\quad$ ім. . р нК , 2012. - . 104-114.

5. $р у с \kappa$. етодичні спекти кл сифік ції і п спортиз ції геологогеоморфологічних п м'яток природи / . рус к, . кун // існ. ьвів. ун-ту. ер. геогр. - 2011. - ип. 39.- . 44-51.

6. $р у с \kappa$. м'ятки неживої природи лицького р йону в но- $\mathrm{p}$ нківської обл сті: суч сний ст н т перспективи екотуристичного використ ння / . pус к, . юнов // роблеми геоморфології і п леогеогр фії кр їнських рп т і прилеглих територій : б. н ук. пр ць. - ьвів : $.158-171$

7. $р у с \kappa$. . ерспективи екотуристичного використ ння п м'яток неживої природи лицького $\mathrm{p}$ йону в но- $\mathrm{p}$ нківської обл сті т створення геоп рку “ лицьке ридністер'я” / . . рус к // рп тський кр й : н укові студії з історії, культури, туризму. - 2013. - № 1 (3). - . 177-188.

8. н тюк. . озріз верхньоплейстоценового грунтово-лесового покриву в р йоні п леолітичної стоянки ежигірці 1 ( лицьке ридністер'я) // існик ьвів. ун-ту. ер. геогр. - 2011. - ип. 39. - .95-112.

9. риценко . . еологічні п м’ятки природи кр їни : проблеми вивчення, збереження т р ціон льного використ ння / . . риценко, . . щенко, . . усько, . . евченко. - ., 1995. - 60 с.

10. інько . л сифік ція і територі льне пл нув ння природоохоронних геоморфологічних об'єктів / . інько // існик ьвів. ун-ту. ер. геогр. - 1998. - ип. 21. .130-133.

11. інько . повідні геоморфологічні об’єкти кр їнських рп т: структур , особливості поширення т використ ння / . інько, . руск, . н тюк, . обзяк // роблеми геоморфології і п леогеогр фії кр їнських рп т і прилеглих територій : м тері ли іжн р. семін ру, присв. 90-річчю від дня н родж. проф. . ися. - ьвів : ім. . р нК , 2004. - .260-280.

12. інько . . роектов ні геоп рки хідної кр їни / . . інько, . . евчук // ізичн геогр фія т геоморфологія. - 2011. - ип. 3 (64). - .41-55.

13. л пиук. . овые д нные о п леолите и мезолите в в но- $\mathrm{p}$ нковской обл сти / . . л пчук, . . икитенко // рхеологические открытия 1975 г. ., $1976 .-.335$. 
14. л пчук . . овые д нные о п леолите и мезолите рик рп тья / . . л пчук // ов. рхеология. - 1983. - № 4. - . 103-118.

15. лnчук . . озднеп леолитическ я стоянк ежигирцы 1 / . . л пчук // р ткие сообщения н-т рхеологи . . 1981. - ып. 165. - . 58-63.

16. ов льськ . . собливості к рстового рельєфу території лицького н ціон льного природного п рку / . . ов льськ // хорон і менеджмент об'єктів неживої природи н з повідних територіях : м тері ли іжн р. н ук.-пр кт. конф. рим йлів, ернопіль: жур , 2008. - . 136-139.

17. ов льськ . . тр ктивні об'єкти неживої природи лицького використ ння у рекре ції / . . ов льськ // екре ційний потенці л рик рп ття: історія, суч сний ст н, перспективи. - ип. 2 : м тері ли н ук.-пр кт. конф. в но- р нківськ: олі нт, 2010. - . 143-148.

18. ов льськ . . уч сний ст н розвитку туризму у лицькому н ціон льному природному п рку / . . ов льськ // уристичні ресурси як чинник розвитку території : м тері ли сеукр. н ук.-пр кт. конф. - ернопіль : ид-во ім. . н тюк , 2012 - .281-284.

19. оротенко . . еологические п мятники кр ины : спр вочник-путеводитель / . . оротенко, . . ириц , . . невский и др. - иев : ук. думк , 1987. $156 \mathrm{c}$.

20. р вчук . . еоморфологія ередк рп ття / . . р вчук. - ьвів : iм. . p HK , 1999. - $187 \mathrm{c}$.

21. $p$ вчук. роектов ні геоп рки кр їнських рп т як демонстр ційні моделі еволюції емлі / . р вчук, . огуцький, . рус к [т ін.]// ук. вісник ернів. ун-ту. - 2012. - ип. 612-613 : еогр фія. - . 102-107.

22. онч $\kappa$. . еологічний путівник в но- р нківської обл сті / . . онч к, . . тельм х, . . омин. - в но- р нківськ : ілея- ,2010. - 240 с.

23. удницький . н доби до морфології подільського сточищ ністр / . удницький // бірник пр ць . . 1913. - .16. -311 с.

24. риходько . . риродно-з повідні території т об'єкти в но- р нківщини / . . риходько, . . бр мюк, . . ойчук. - в но- р нківськ, 2000. - 272 с.

25. роект орг ніз ції території лицького , охорони, відтворення і рекре ційного використ ння природних комплексів і об'єктів / . руск, . р м рець, - н тюк [т ін.]. - ьвів, 2012. - .1. -546 с.

26. роект орг ніз ції території лицького , охорони, відтворення і рекре ційного використ ння природних комплексів і об’єктів / . рус к, . р м рець, . убер [т ін.]. - ьвів, 2012. - . 2. -308 с.

27. итник. . тр тифіков ні п м'ятки п леоліту в околицях лич / . . итник, . . огуцький, . . ул ковськ // рхеологія. - 1996. - № 3. . 86-97.

28. итник . омплексні рхеологічно-геологічні дослідження п леолітичного поселення лич // . итник, . огуцький // ові технології в рхеології. - иїв; ьвів, 2002. - . 189-202.

29. ись . . еоморфологія / . . ись. - ьвів : ид-во ьвів. ун-ту, 1962. $222 \mathrm{c}$.

30. евчук . . еотуристичний потенці л в но- р нківщини / . . евчук // екре ційний потенці л рик рп ття: історія, суч сний ст н, перспективи : м теріли іжн р. н ук.-пр кт. конф. - в но- р нківськ: олі нт, 2009. - .352-360. 
31. циишин . сновні ет пи верхньопліоцен-нижньоплейстоценового морфо-, літогенезу долини ністр у р йоні лицького ридністер'я / . цишин // існик ьвів. ун-ту. ер. геогр. - 2010. - ип. 38. - . 379-394.

32. Lessy i paleolit Naddniestrza halickiego (Ukraina) / pod red. T. Madeyskiej // Studia Geologica Polonika. - 2002. - Vol. 119. - 392 s.

33. Sytnik . Naddniestrze Halicza - nowy ośrodek paleolitu na Ukrainie / . Sytnik, A. Bohutskyj // Sprawozdania z czynności i posiedzeń Polskiej Akademii Umiejętnosci. - 2001. - . 64. - S. 208-211.

m ття: н дійшл до ред кції 13.10.2014

доопр иьов н 03.11 .2014

прийнят до друку 19.11.2014

\section{NON-LIVING NATURE MONUMENTS OF HALYCH-DNIESTER REGION: STATE OF PROTECTION AND PERSPECTIVES OF GEOTOURISTIC APPLICATION}

\section{Vitaliy Brusak, Sofia Paljanycja}

Ivan Franko National University of Lviv, P. Doroshenko Str., 41, UA-79000 Lviv, Ukraine

The list of non-living nature geological, geomorphological, hydrological monuments of Halych National Park in Halych-Dniester region is submitted in this article and its current state of protection is characterized. The opportunities of application of non-living nature monuments in recreation and tourism activities of Halych National Park are analyzed. The network of one-day and multi-day geotouristic trails are developed. The perspectives of creation of National geopark "Halych-Dniester region" are regarded.

Key words: monuments of non-living nature, geological, geomorphological and hydrological monuments of nature, geotouristic trails, National geopark, Halych-Dniester region, Halych National Park. 